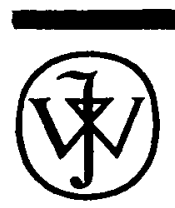

\section{GLACIAL AND QUATERNARY GEOLOGY \\ by Richard Foster Flint, Yale University.}

A reference work on climatic change and glaciation through the last ten million years. includes most recent data showing that glacial ages extend much further back in time than previously thought. Covers changes in climate, vegetation, animal populations, and pluvial phenomena in the late Cenozoic time.

due May 1971

Approx. 906 pages

$£ 10.95$

\section{PETROLEUM GEOLOGY OF THE UNITED STATES}

by Kenneth K. Landes, University of Michigan. A comprehensive coverage of the actual and potential oil and gas producing areas of the United States in regard to areal and structural geology, stratigraphy, and known traps. Illustrations include index, geologic, tectonic, and oil and gas field maps; stratigraphic charts, cross-sections, and structure contour and lithofacles maps. Emphasis is on future petroleum possibilities in the United States.

572 pages $£ 11.75$

\section{VERTEBRATE PALEOZOOLOGY}

by Everett C. Olson University of California, Los Angeles.

Considers in detail the major problems encountered in understanding the nature and evolution of extinct vertebrates. Treats the adequacy of the record and the bases for interpretation of morphology, systematics, and evolutionary patterns.

due May $1971 \quad$ approx. 760 pages

$£ 14.25$

\section{THE TECTONICS OF THE APPALACHIANS}

by John Rogers, Yale University.

Presents an up-to-date structural synthesis of the sedimentary metamorphic regions of the Appalachians. Historically views the growth of this vast mountain chain, and tests concepts of mountain building and global tectonics now being evolved from geophysical studies of oceans and their floors. (DeSitter Regional Geology Series.)

292 pages $£ 11.50$

\title{
A new paperback
}

\section{The Elements of Palaeontology}

\section{R.M.BLACK}

This book is written primarily for the use of students who require a knowledge of a wide field in palaeontology at an introductory level. All the major groups of invertebrate fossils are dealt with, and an outline of the palaeontology of the vertebrates and plants is included. Some emphasis is given to biological aspects of palaeontology since it is becoming increasingly clear that the interpretation of fossils and fossil assemblages, from a biological point of view, throws much light on wider geological problems in sedimentation, stratigraphy, and palaeontology.

'... a beautifully illustrated palaeontological textbook... praised for its breadth of scope and general high quality of its numerous photographs'.

Nature

Paperback $£ 2.25$ net Cloth $\mathbf{f 4 . 5 0}$ net

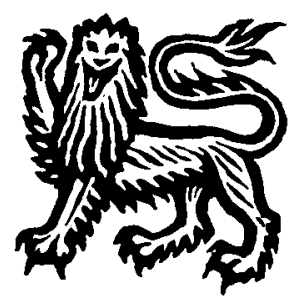

CAMBRIDGE

UNIVERSITY PRESS 
Now available in English...

FOSSIL FORAMINIFERA OF THE U.S.S.R.

(Globigerinidae, Hantkeninidae \& Globorotaliidae) by N. N. Subbotina. Translated from the Russian in co-operation with the National Lending Library for Science and Technology, 1971.

Cloth, $22 \times 15 \mathrm{~cm}$., $321 \mathrm{pp}$. with 41 full page plates each illustrating up to 40 types and variations, with detailed descriptions. Bibliography.

SBN 569-06261-6 Price: $£ 7.50$

This monograph, published in USSR in 1953, incorporates many new species described originally in Russian texts. Much will, therefore, be new and welcome to workers who have been unable to read the original.

Tables for identification of genera are valuable. The detailed taxonomic account is preceded by a review of general aspects of the subject including biology, ecology, variability of species and the significance of the study to stratigraphy. Northants. 


\section{NOTES FOR GONTRIBUTORS}

Articles submitted for publication in the Geological Magazine should be addressed to the editors at the Sedgwick Museum, Downing Street, Cambridge $\mathrm{CB}_{2}{ }_{3} \mathrm{EQ}$, England, and sent in duplicate. Publications for notice and review should be marked for the review editor at the same address.

Gontributions, including reference lists, should be typewritten, double-spaced, and should be carefully revised. Where typing errors are corrected or minor alterations made, they should be done neatly in the typescript, leaving the margins clear. Marginal marks should be used only when correcting proofs. Illustrations should be drawn to allow reduction to a maximum size of $165 \mathrm{~mm} \times$ I Iomm; originals must not exceed $495 \mathrm{~mm} \times 330 \mathrm{~mm}$ and must be sent in a flat package. Lettering must allow for legibility after reduction (i.e. equivalent to $\mathrm{Imm}$ as a minimum on reduction). Duplicates of illustrations may be prints or, preferably, reductions. Metric units of the SI system are preferred. Illustrations in the text will be referred to as figures (Fig. 2, 2a, etc.), and halftone plates will be referred to (also in arabic) as Plates 2, 2a, etc. Folding plates will not be accepted. Gaptions must be typed on separate sheets.

The typescript must be accompanied by a short summary. Contributors should follow the rules in the Geological Society of London's Notes to Authors (Proc. geol. Soc. Lond., No. 1627, Oct. 1965), with the following exceptions. The total length of a paper should not in general exceed 20 pages of the Geological Magazine; preference and priority are given to short papers. Primary headings should be in lower case, at margin, with arabic numeral. Secondary headings should be in lower case italics (underlined), at margin, with Section number followed by lower case letter ( I.a, r.b, etc.). Tertiary headings should be in lower case italics (underlined), at margin, with Section number, lowercaseletter, and number of sub-section (I.a.I, I.a.2, etc.).

No cross-references by page should be given to other parts of the text, but 'above' and 'below' used (with the section specified, e.g. 'Section 2 a. $I$. '). References should be abbreviated in the form of the World List of Scientific Periodicals (4th edit., I $963-65$ ) as far as possible. e.g. Lapworth, G. 1878. The Moffat Series. Q. Fl geol. Soc., Lond., 34, 240-343. Books should be cited briefly as: Burns, R. G. 1970. Mineralogical applications of crystal field theory. 224 p., G.U.P., London. Unpublished work, e.g. from theses, should normally be referred to in the text in parentheses and not included in the reference list unless already in the press. 'In the interests of authors, copyright is assigned to Cambridge University Press.'

Twenty-five offprints of each paper will be provided free of charge. Additional offprints may be purchased according to an agreed scale of charges. 


\section{Geological Magazine \\ Volume 108, Number 3, May i97 I}

LEMON, G.G.

The Pre-Cambrian rocks of the N.E. Ox Mountains, Eire.

VELDE, DANIELLE

A note on an analcite-bearing lamproite from Devonshire.

$20 \mathrm{I}-204$

FOX, J.S.

Coexisting chloritoid and staurolite and the staurolitechlorite isograd from the Agnew Lake area, Ontario, Canada.

KENNAN, P.S.

Porphyroblast rotation and the kinematic analysis of a small fold.

DAS, B.K. \& VANSHNARAYAN

Nahan Sandstone and its exfoliation, Nainital District, Uttar Pradesh, India.

DAVIES, R.G. \& CRAWFORD, A.R.

Petrography and age of the rocks of Bulland Hill, Kirana Hills, Sarghoda District, West Pakistan.

ORAJAKA, S.

The petrography and chemistry of the Obudu type hornblende peridotite (cortlandtite), Ogoja Province, Eastern Nigeria.

GHOWDHARY, P.K.

Zircon populations in Lewisian quartzite, gneiss and granite north of Loch Laxford, Sutherland.

$255^{-262}$

\section{GORRESPONDENCE}

Comments on the Llandovery Series and use of Welsh placenames: T. Neville George and L.R.M. Cocks \& P. Toghill.

REVIEWS

$263-265$

REVIEWS

$266-269$

PUBLICATIONS RECEIVED

NOTICE

(C) Cambridge University Press 1971

Printed in Great Britain by Alden \&o Morwbray Ltd at the Alden Press, Oxford 